Proceedings of XIX International Scientific Conference "New Technologies and Achievements in Metallurgy, Material Engineering, Production Engineering and Physics", Częstochowa, Poland, June 7-8, 2018

\title{
Analysis of Phase Precipitation in Sanicro 25 Austenitic Steel after Ageing
}

\author{
M. SROKA ${ }^{a, *}$, A. ZiELIŃSKI ${ }^{b}$ AND G. GOLAŃSKI ${ }^{c}$ \\ ${ }^{a}$ Silesian University of Technology, S. Konarskiego 18A, 44-100 Gliwice, Poland \\ ${ }^{b}$ Institute for Ferrous Metallurgy, K. Miarki 12-14, 44-100 Gliwice, Poland \\ ${ }^{c}$ Częstochowa University of Technology, al. Armii Krajowej 19, 42-200 Częstochowa, Poland
}

\begin{abstract}
This paper presents the analysis of the processes of secondary phase precipitation in Sanicro 25 $(22 \mathrm{Cr} 25 \mathrm{NiWCoCu})$ austenitic steel. The examined material was subject to long-term ageing for the time of annealing up to $10,000 \mathrm{~h}$ at 700 and $750{ }^{\circ} \mathrm{C}$. The performed tests showed the presence of primary MX precipitates and $\mathrm{Z}$ phase. Long-term ageing resulted in the occurrence of the coherent phase rich in $\mathrm{Cu}\left(\varepsilon_{-} \mathrm{Cu}\right), \mathrm{M}_{23} \mathrm{C}_{6}$ carbides, and precipitates of $\mathrm{MX}$ and $\mathrm{NbCrN}$.
\end{abstract}

DOI: 10.12693/APhysPolA.135.207

PACS/topics: Sanicro 25, microstructure, precipitation, ageing

\section{Introduction}

In spite of the development of renewable energy sources (RES) that has been promoted for years, not only in Europe but also in the world's power industry, the global energy sector is still based mostly on fossil fuels. Also, despite the rise in pricing for the emission of harmful gases into the atmosphere, which is to significantly curb the development of conventional energy, no prospects for changing the proportion of the sources of electricity generation in the coming years are seen [1-3]. Therefore, in order to reduce the costs of electricity generation, the modernisation of "old" power units (mostly of $200 \mathrm{MW}$ ) built in the years 1960-1970 and the construction of modern supercritical power units have been carried out in Poland for several years. The increase in the performance of newly built power units results at the same time in the increase in their efficiency. It is inseparably connected with the need to use materials with increased functional properties [4-7].

One of such materials is the Sanicro 25 steel (marked X7NiCrWCuCoNbNB25-23-3-3-3-2 according to the EN standards), which was developed by AB Sandvick Material Technology. This steel is marked by high contents of nickel $(24 \%)$, chromium $(22 \%)$, and tungsten $(3 \%)$, as well as the addition of elements such as niobium, cobalt, and copper. It is primarily intended for components of steam superheaters operating at up to $700^{\circ} \mathrm{C}[1,8]$.

In the as-received condition, the Sanicro 25 steel is characterised by the austenitic microstructure with MX and $\mathrm{Z}$ phase $(\mathrm{NbCrN})$ precipitates. The presence of $\mathrm{MX}$ and $\mathrm{Z}$ phase precipitates in its structure and the solution strengthening by tungsten and nitrogen atoms makes the Sanicro 25 have higher creep strength than other steels

*corresponding author; e-mail: marek.sroka@polsl.pl with austenitic structure, i.e. HR3C and Super 304H. These data are the basis for using this steel in supercritical and ultra-supercritical boilers. The creep strength determined for $100,000 \mathrm{~h}$ at $700^{\circ} \mathrm{C}$ is $95 \mathrm{MPa}$, and it is comparable to that of the HR6W nickel-base alloy $[1,8,9]$. High functional properties of the Sanicro 25 steel were the basis for its implementation in supercritical and ultrasupercritical power units $[1,9]$.

\section{Material and experimental methods}

The Sanicro 25 steel in the as-received condition in the form of a coil specimen of $\varphi 38 \times 8.8 \mathrm{~mm}^{3}$ was taken for testing. Table I presents the chemical composition of the test specimen of steam superheater, which complies with VdTUV 555 of 09.2008 .

TABLE I

The chemical composition of the test material with reference to the requirements of Vd TUV555 09.2008.

\begin{tabular}{c|c|c|c|c|c}
\hline \hline \multicolumn{7}{c}{ Alloying element [wt\%] } \\
\hline $\mathrm{C}$ & $\mathrm{Si}$ & $\mathrm{Mn}$ & $\mathrm{P}$ & $\mathrm{S}$ & $\mathrm{Cr}$ \\
\hline 0.06 & 0.25 & 0.50 & 0.01 & $<0.01$ & 23.0 \\
\hline \hline $\mathrm{W}$ & $\mathrm{Ni}$ & $\mathrm{Co}$ & $\mathrm{Cu}$ & $\mathrm{Nb}$ & $\mathrm{B}$ \\
\hline 3.2 & 24.1 & 1.4 & 2.9 & 0.4 & 0.005
\end{tabular}

The microstructure of the Sanicro 25 steel was observed with Inspect $\mathrm{F}$ scanning electron microscope (SEM) on conventionally prepared electrolytically etched metallographic microsections.

The identification of precipitates was carried out using the selected area electron diffraction by means of a transmission electron microscope Titan 80-300 (TEM) with thin foils.

The quantitative analysis of the precipitates was performed using the computer image analysis. The image analysis system was calibrated using the scale marker as 
in the photos. Calibration coefficient: 1 pixel $=0.040 \mu$ $\mathrm{m}$. The above-mentioned investigations were carried out on the material in the as-received condition and after long-term ageing at 700 and $750{ }^{\circ} \mathrm{C}$ for 1000 and $10,000 \mathrm{~h}$.

\section{Results and discussions}

The microstructure of the Sanicro 25 steel in the asreceived condition is shown in Fig. 1 . The test material is characterised by the austenitic matrix with the grain size of 7 according to the scale of standards with annealing twins and numerous primary precipitates of varying size arranged in bands both within the grains and at the grain boundary. The primary precipitates were observed both inside the grains and at the grain boundaries. The structure of the Sanicro 25 steel is typical of heat-resistant austenitic steels stabilised by niobium.
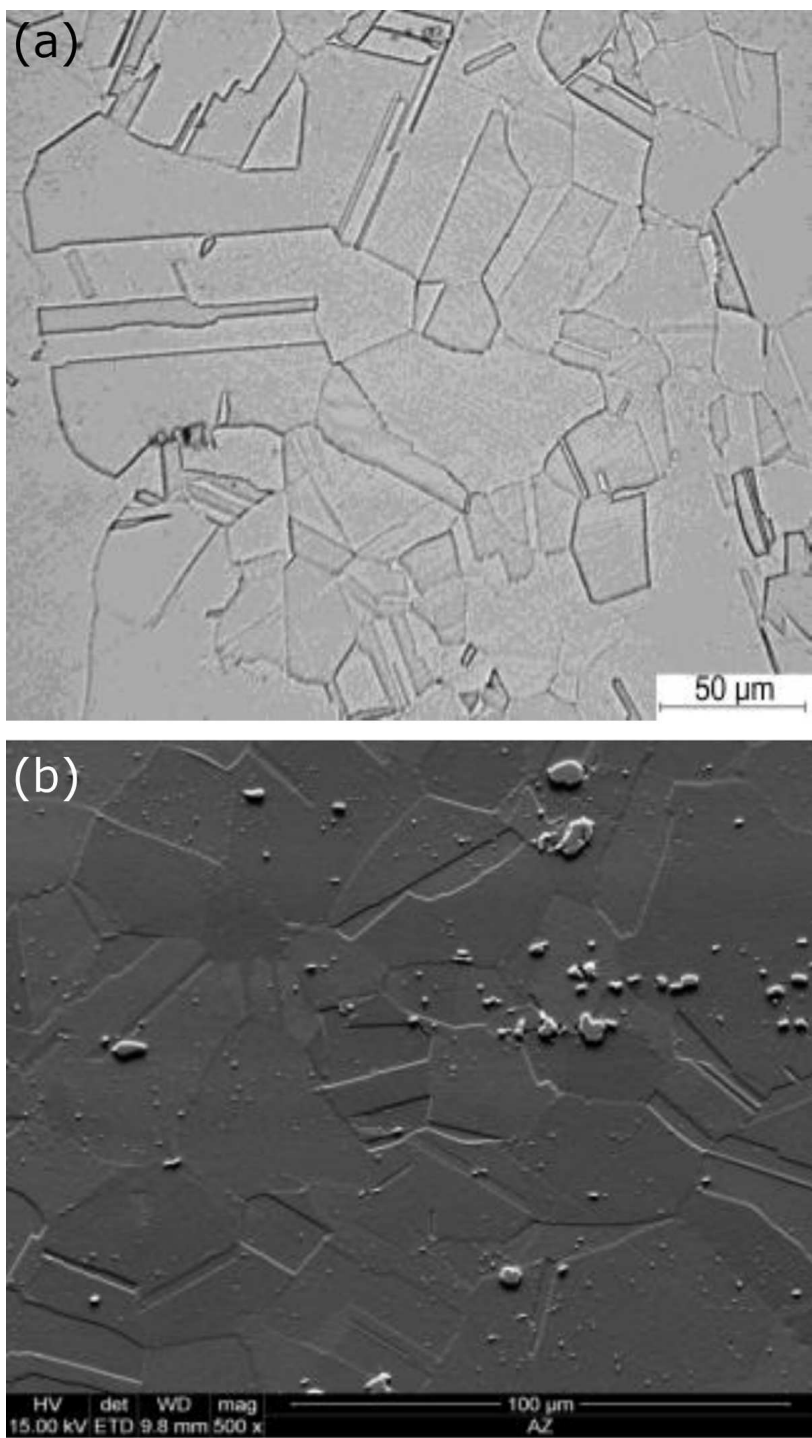

Fig. 1. Microstructure of Sanicro 25 in the as-received condition: (a) LM, (b) SEM.
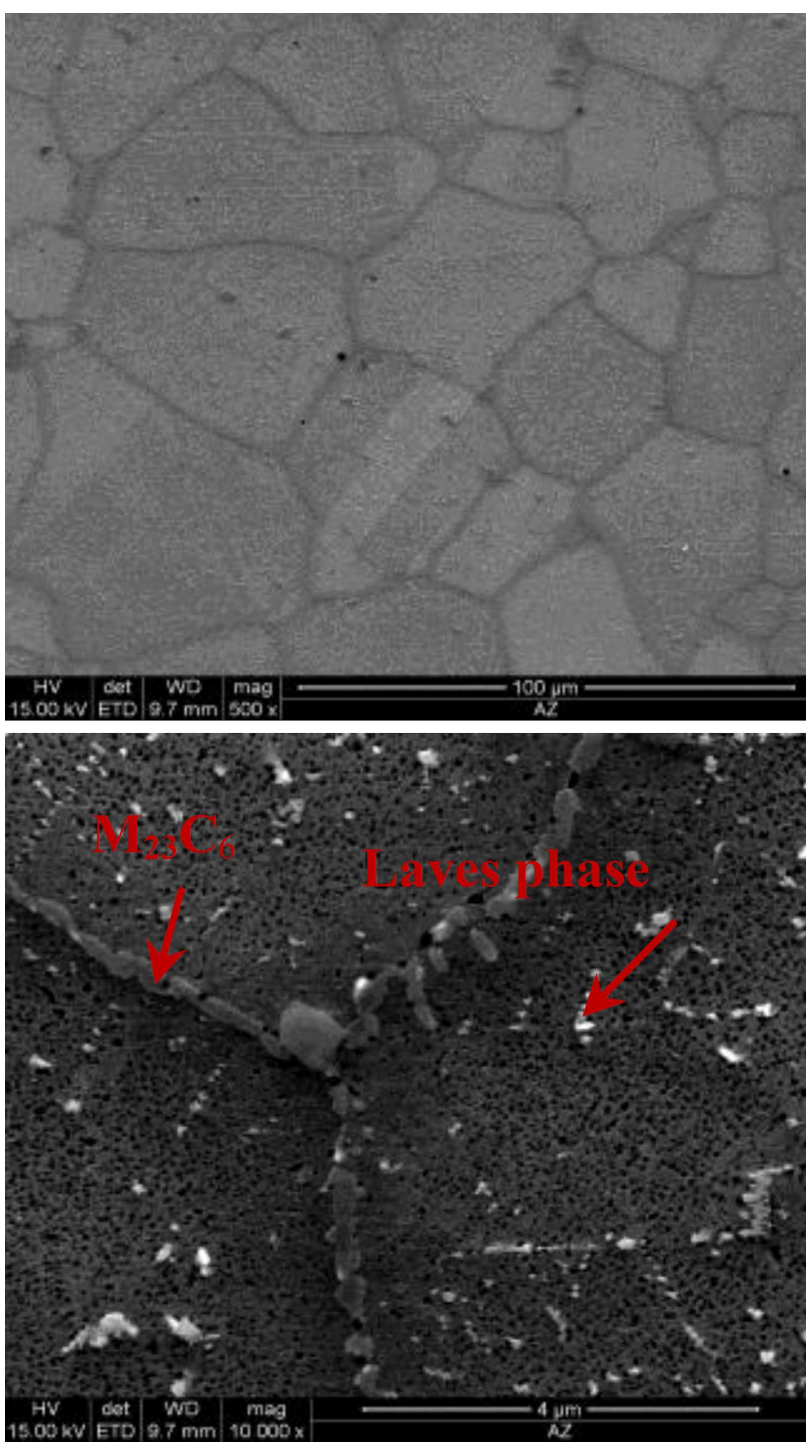

Fig. 2. Microstructure of Sanicro 25 steel after ageing at $700{ }^{\circ} \mathrm{C}$ for $1000 \mathrm{~h}, \mathrm{SEM}$.

Long-term ageing of the Sanicro 25 steel contributes mainly to the processes of secondary phase precipitation (Figs. 2, 3). In the initial period of ageing, numerous very fine copper particles coherent with the matrix (Fig. 4) as well as $\mathrm{M}_{23} \mathrm{C}_{6}$ chromium carbides (Fig. 5) are precipitated. The copper-rich $\left(\varepsilon_{-} \mathrm{Cu}\right)$ precipitates in austenitic steels are observed just after one hour of ageing at $650^{\circ} \mathrm{C}[10]$. Due to their nanometric dimensions, these precipitates strengthen the alloy very intensively $[10,11]$. The Cu-rich particles are observed inside the grains, while $\mathrm{M}_{23} \mathrm{C}_{6}$ carbides were precipitated at the grain boundaries. In contrast to $\varepsilon \mathrm{Cu}$ precipitates, $\mathrm{M}_{23} \mathrm{C}_{6}$ carbides have lower thermodynamic stability, which results in their high tendency to coagulate and create the so-called continuous network of precipitates at the grain boundaries $[12,13]$.

The extension of the ageing time, especially at $750{ }^{\circ} \mathrm{C}$, contributes to the intensification of precipitation of finely 

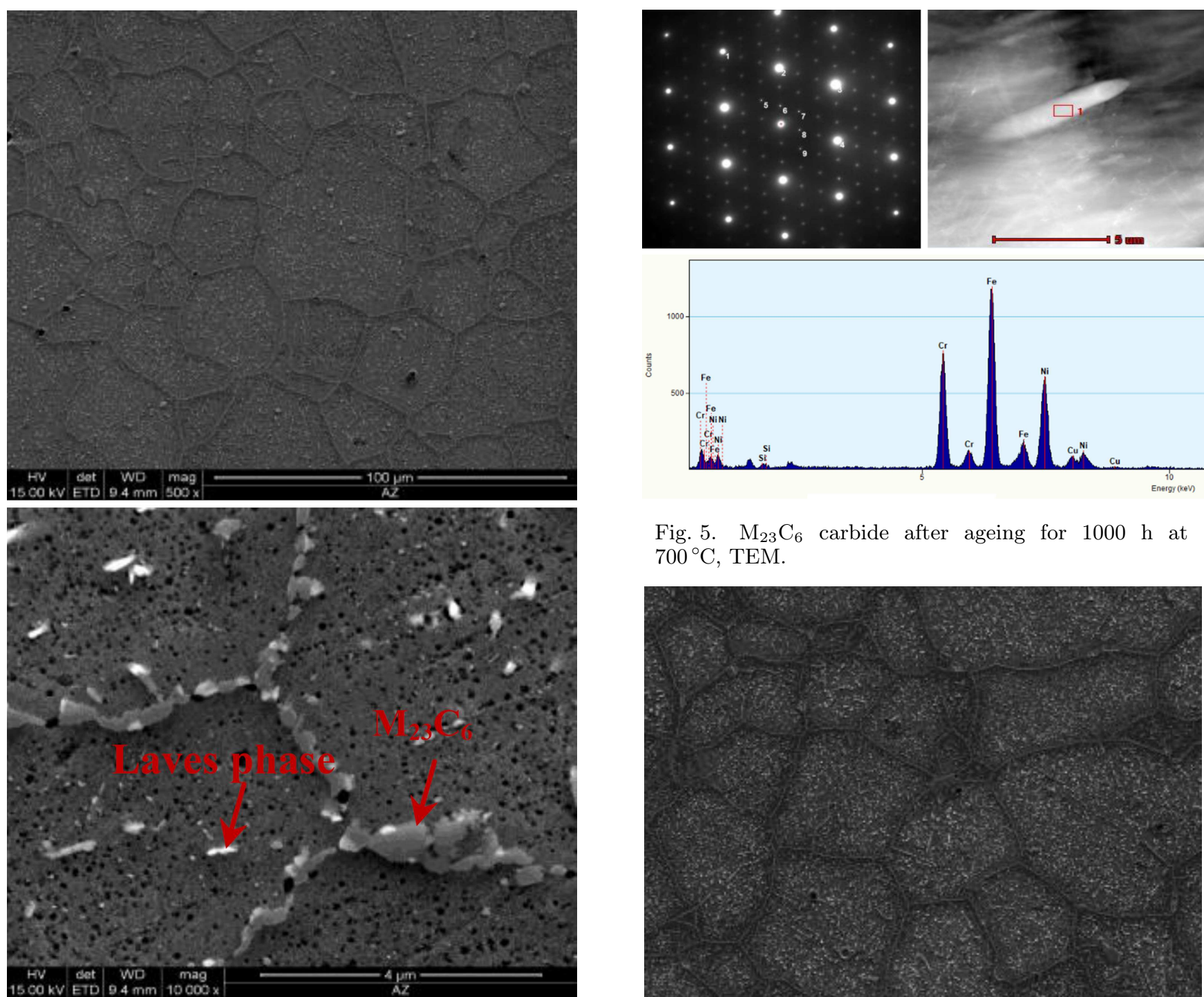

Fig. 5. $\mathrm{M}_{23} \mathrm{C}_{6}$ carbide after ageing for $1000 \mathrm{~h}$ at $700{ }^{\circ} \mathrm{C}$, TEM.
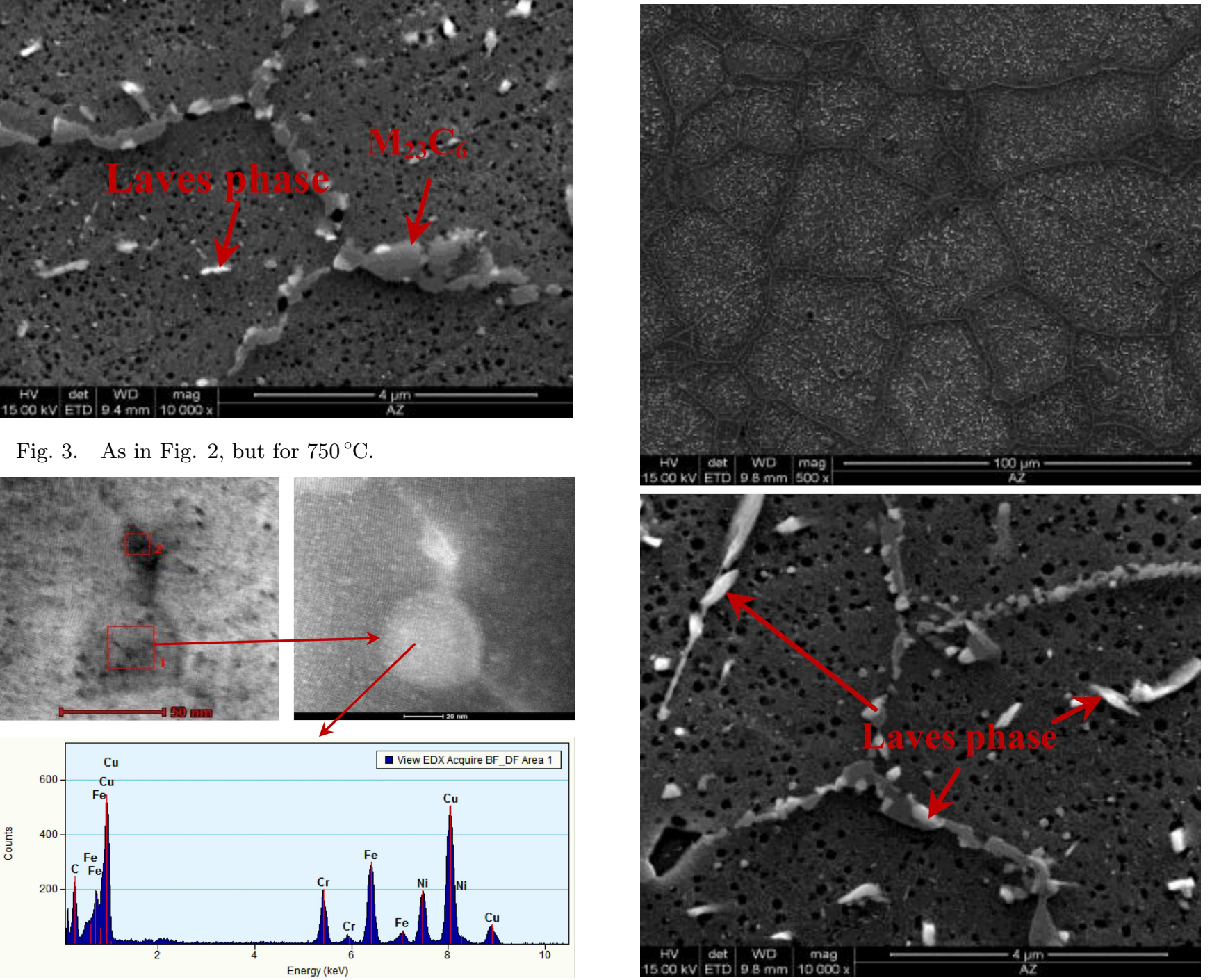

Fig. 4. Copper-rich precipitates after ageing for $1000 \mathrm{~h}$ at $700{ }^{\circ} \mathrm{C}$, TEM.

Fig. 6. Microstructure of Sanicro 25 steel after ageing at $750{ }^{\circ} \mathrm{C}$ for $10,000 \mathrm{~h}, \mathrm{SEM}$ observation. 
dispersed $\mathrm{Z}$ phase and coagulation of $\mathrm{M}_{23} \mathrm{C}_{6}$ carbides. The finely dispersed secondary precipitates of the $\mathrm{Z}$ phase inside the grains result in the strong strengthening of the alloy similarly to the $\varepsilon_{-} \mathrm{Cu}$ particles. The $\mathrm{Z}$ phase precipitates are also characterised by high stability up to approximately $700^{\circ} \mathrm{C}[13,14]$. After $1000 \mathrm{~h}$ ageing at 700 and $750{ }^{\circ} \mathrm{C}$, fine Laves phase precipitates $\left(\mathrm{Fe}_{2}\right)$ were revealed, too (Figs. 2, 3). The Laves phase precipitates were observed both inside the grains and at the grain boundaries. Fine particles of $\mathrm{M}_{23} \mathrm{C}_{6}$ carbides and the Laves phase precipitates at the grain boundaries have a positive effect on the increase in creep strength by inhibiting slippage at the grain boundaries $[12,13,15]$.
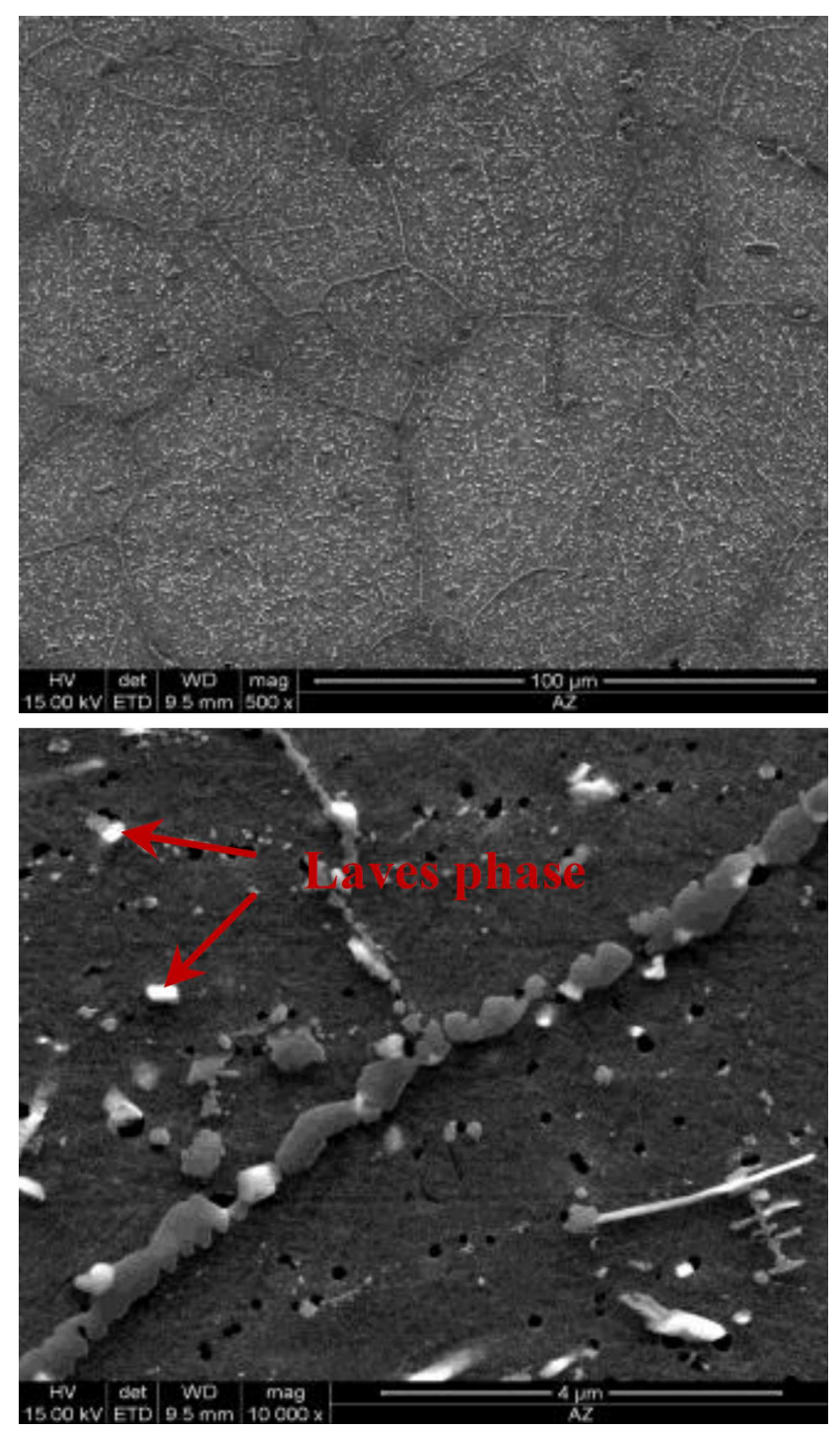

Fig. 7. As in Fig. 6, but for $750{ }^{\circ} \mathrm{C}$.

After $10,000 \mathrm{~h}$ ageing, the increase in the size of precipitates of this phase was observed (Figs. 6, 7). The effect of the Laves phase precipitated inside the grains on steel properties depends on its size and volume fraction. The finely dispersed Laves phase particles precipitated inside the grains have a positive effect on creep and fatigue strength. The coagulation of the Laves phase during service results in the disappearance of this positive effect $[9,16]$.

\section{Summary}

The identification of precipitates in the Sanicro 25 steel in the as-received condition and after ageing at 700 and $750^{\circ} \mathrm{C}$ for 1000 and $10,000 \mathrm{~h}$ showed that:

- in the as-received condition, there are only primary MX precipitates and $\mathrm{Z}$ phase in the structure;

- ageing leads to the precipitation of copper-rich $\left(\varepsilon \_\mathrm{Cu}\right)$ particles, the Laves phase and secondary $\mathrm{Z}$ phase precipitates in the matrix, while at the grain boundaries the occurrence of $\mathrm{M}_{23} \mathrm{C}_{6}$ and the Laves phase precipitates were observed;

- longer ageing times at the temperature of the experiment lead to the coagulation of $\mathrm{M}_{23} \mathrm{C}_{6}$ carbides and Laves phase precipitates.

The findings discussed above are part of the system being developed as the material characteristics, which is the basis for predicting the service life of the material of components operating under creep conditions [16-19].

\section{Acknowledgments}

The results in this publication were obtained as part of the research co-financed by the National Science Centre under contract 2011/01/D/ST8/07219 — Project: "Creep test application to model lifetime of materials for modern power generation industry" and rector's grant in the area of scientific research and development works, Silesian University of Technology, 10/010/RGJ18/0201.

\section{References}

[1] A. Hernas, A. Dobrzański, J. Pasternak, S. Fudali, Characteristics of a new generation of materials for the power industry, Publishing House of Silesian University of Technology, Gliwice 2015.

[2] L.A. Dobrzański, W. Borek, J. Mazurkiewicz, Materialwiss. Werkst. 47, 428 (2016).

[3] T. Tański, M. Sroka, A. Zieliński, in: Creep, Eds. T. Tański, M. Sroka, A. Zieliński, InTech, Croatia, Rijeka 2018, p. 1.

[4] A. Zieliński, M. Sroka, A. Hernas, M. Kremzer, Arch. Metall. Mater. 61, 761 (2016).

[5] M. Król, T. Tański, Arch. Metall. Mater. 61, 945 (2016).

[6] M. Sroka, A. Zieliński, A. Hernas, Z. Kania, R. Rozmus, T. Tański, A. Śliwa, Metalurgija 56, 333 (2017).

[7] A. Śliwa, W. Kwaśny, W. Sitek, M. Bonek, Arch. Metall. Mater. 61, 481 (2016). 
[8] A. Zieliński, J. Dobrzański, H. Purzyńska, R. Sikora, M. Dziuba-Kałuża, Z. Kania, Arch. Metall. Mater. 62, 2057 (2017).

[9] G. Golański, A. Zielińska-Lipiec, A. Zieliński, M. Sroka, J. Mater. Eng. Perform. 26, 1101 (2017).

[10] J.W. Bai, P.P. Liu, Y.M. Zhu, C.Y. Chi, X.Y. Yu, X.S. Xie, Q. Zhan, Mater. Sci. Eng. A Struct. 584, 57 (2013).

[11] Ch.-Y. Chi, H.-Y. Yu, J.-X. Dong, X.-S. Xie, X.-F. Chen, F. Lin, Acta Metall. Sin. 24, 141 (2011).

[12] T. Sourmail, Mater. Sci. Techn. 14, 1 (2001).

[13] J.-Z. Wang, Z.-D. Liu, H.-S. Bao, S.-C. Cheng, B. Wang, J. Iron Steel Res. Int. 20, 54 (2013).
[14] V. Vodarek, Sci. Mater. 66, 678 (2012).

[15] G. Chai, M. Bostrom, M. Olaison, U. Forsberg, Proced. Mater. Sci. 55, 232 (2013).

[16] A. Zieliński, J. Dobrzański, H. Purzyńska, G. Golański, Mater. Test. 57, 859 (2015).

[17] L.A. Dobrzański, A. Śliwa, W. Sitek, Surf. Eng. 5 ISEC, 26 (2006).

[18] A. Zieliński, G. Golański, M. Sroka, Int. J. Pres. Ves. Pip. 152, 1 (2017).

[19] G. Golański, A. Zieliński, A. Zielińska-Lipiec, Materialwiss. Werkst. 46, 248 (2015). 